\title{
Productive and Reproductive Performance of Syrian Shami Cows
}

\author{
O. Almasri ${ }^{1}$, S. Abou-Bakr ${ }^{2}$ and M. A. M. Ibrahim ${ }^{2}$ \\ 1- General Commission for Scientific Agricultural Research, Damascus, Syria. \\ 2- Department of Animal production, Faculty of Agriculture, University of Cairo, Giza, Egypt. \\ Corresponding author: obaidaalimasri@gmail.com
}

\begin{abstract}
Summary
The objectives of this study were to characteristic productive and reproductive traits of native Shami cows in Syria and to study the effect of nongenetic factors on their productive and reproductive traits. In this study, 2654 records were collected on 605 cows from 1980 to 2010 of Deir al-Hajar station in Syria. Data were analysed using the General Liner Model (XLSTATE. 2019).

The least squares means for age at first calving (AFC), calving interval (CI), total milk yield (TMY), daily milk yield (DMY), lactation period (LP) and dry period (DP) were 30.9 \pm 0.16 months, $454 \pm 0.16$ days, $1503 \pm 0.16$ $\mathrm{kg}, 9.1 \pm 0.16 \mathrm{~kg}, 163 \pm 0.16$ days and $292 \pm 34$ days, respectively.

The results showed that year of birth had a significant $(\mathrm{p}<0.01)$ effect on age at first calving. While season of birth haven't significant effect on (AFC). Also, results showed that year of calving and parity had a significant $(p<0.01)$ effect on all studied traits. Season of calving had significant $(p<0.01)$ effect on all studied traits except for dry period.

Improve management conditions and genetic improvement for Syrian native Shami cows could be improve reproductive performance that leads to increase milk yield and number of calvings of their cows.
\end{abstract}

Key words: Productive, Reproductive, Performance, Syrian Shami cows.

\section{Introduction}

The increase in milk production in dairy cows are associated with decreasing in reproductive efficiency, as a result of a negative correlation between reproductive and productive performance of high yielder cows in different breeds (Chagas et al, 2007).

Age at first calving and calving interval reflect the reproductive efficiency of cows (Alemayehu and Moges, 2014). Age at first calving (AFC) is an important trait that reflects growth rate of heifers. Optimal AFC should be closed to 24 months because it optimizes the life of the productive cow and increase number of calving in their lifetime (sawa et al, 2019). Calving interval (CI) should be optimal for increasing the number of calvings and decreasing drying off periods that leads to get more milk produced from cows during their productive life. Azizunnesa (2002) noted that farms with $\mathrm{CI}$ of 13 to 15 months had higher economic returns.

Dry period is necessary for cows before calving to regenerate their mammary glands and to get high milk production during the subsequence parity. Most studies showed the typical dry period is closed 60 days (Sawa et al. 2013). shortening or omitting the dry period may result in a lower yield in next lactation and lighter calves (Sawa et al. 2012).

However, poor genetic capacity of the native cattle, inadequate feeding, disease and mismanagement contributed significantly to late age at first calving, long calving interval, short lactation length and low milk production (Masama et al, 2003).

A little of reports were found related to productive and reproductive performance of native Shami in Syria. So, the objectives of this investigation were to characteristic productive and reproductive traits of native Shami cows in Syria and to study the effect of nongenetic factors on their productive and reproductive traits.

\section{Materials and Methods}

\section{Data}

Data used in this investigation were collected from 2654 records are covered 31 years (1980-2010). These records are relevant to 605 native Shami cows which belong to the Deir al-Hajar station in Syria. Deir alHajar is located about $35 \mathrm{~km}$ from Damascus City near Damascus International Airport. It is characterized by hot summer weather and cold winter and temperatures vary greatly between day and night. The day is very windy most of the time, making difficult environmental conditions and therefore the region is severely poor in green vegetation where pastoral vegetation and desert thorns are available.

\section{Herd management}

Animals were housed free system in semi-closed sheds with concrete floors, feeds were offered twice a day. It provides roughage (straw and cotton seed hulls) and then provides concentrated feed (commercial concentrate for lactating cows or ration formulated in station), in addition to provide hay (Vetch, barley and alfalfa) and green feed if available. Water was also available. Heifers were naturally inseminated for the first time when they reach the age of 18 months taking into account the weight of the animal. Cows were machine milked twice a day at 06.00 a.m. and 6.00 p.m., where the calves bring along with their mothers (stimulation of the mothering phenomena). 


\section{Studied traits:}

a- Productive traits:

1-Total Milk Yield (TMY, kg): milk production during lactation period.

2- Daily Milk Yield (DMY, kg): total milk yield / lactation period.

3- Lactation Period (LP, days): number of days of milk.

4-Dry Period (DP, days): number of days between drying-off date and the date of the next calving.

\section{b- Reproductive traits:}

1- Age at First Calving (AFC, month): the number of days between date of birth and date of the first calving of a cow divided by 30.5 .

2- Calving Interval (CI, days): the number of days occurring between two successive calvings.

\section{Statistical analysis}

Data were subjected to statistical analysis of variance as repeated measurements, using the General Linear Model of (XLSTAT 2019.1.2.56963 program).

The two statistical models were used as following: First model for age at first calving trait:

Yijk $=\mu+Y i+S j+e i j k$

Where:

Yijk = the observation of age at first calving.

$\mu=$ the overall mean.

$\mathrm{Yi}=$ the fixed effect of $\mathrm{i}^{\text {th }}$ year of birth $(\mathrm{i}=1,2,3,4$, $5,6)$, where $1=1980-1984,2=1985-1989$, $3=$ $1990-1994,4=1995-1999,5=2000-2004$ and $6=$ 2005-2009.

$\mathrm{Sj}=$ the fixed effect of $\mathrm{j}^{\text {th }}$ season of birth $(\mathrm{j}=1,2,3$, 4 ), where $1=$ winter, $2=$ spring, $3=$ summer and $4=$ autumn.

eijk $=$ the experimental error.

Second model for the rest of studied traits:

$Y i j k l=\mu+Y i+S j+P k+e i j k l$

Where:

Yijkl=the observations of productive and reproductive traits.

$\mu=$ the overall mean.

$\mathrm{Yi}=$ the fixed effect of $i^{\text {th }}$ year of calving $(i=1,2,3$, $4,5,6)$, where $1=1981-1985,2=1986-1990,3=$ $1991-1995,4=1996-2000,5=2001-2005$ and $6=$ 2006-2010.

$\mathrm{Sj}=$ the fixed effect of $\mathrm{j}^{\text {th }}$ season of calving $(\mathrm{j}=1,2$, $3,4)$, where $1=$ winter, $2=$ spring, $3=$ summer and $4=$ autumn.

$\mathrm{Pk}=$ the fixed effect of $\mathrm{k}^{\text {th }}$ parity, where $(\mathrm{k}=1,2,3,4$, $\geq 5$ ).

eijkl $=$ the experimental error.

\section{Results and Discussion}

1- Characteristics of the productive and reproductive traits: A-Productive traits:
1-Total milk yield (TMY):

Table (1) showed the TMY was $1503 \pm 17.74 \mathrm{~kg}$ higher than values reported by $(339.2 \mathrm{li}$, Ayeneshet et al, 2018; $819.89 \mathrm{~kg}$, Basak and Das, 2018 and $636 \mathrm{~kg}$, Toure et al, 2019) on native cows in Ethiopia, India and Mali, respectively.

2-Daily milk yield (DMY):

The Least square mean for daily milk yield DMY in Shami cows was $9.1 \pm 0.06 \mathrm{~kg}$ (table 1 ). Which was higher than $(3.05 \mathrm{~kg}$, Toure et al, 2019; $6.08 \mathrm{~kg}$, Bahashwan, 2020) on native cows in Mali and Dhofari cattle in Sultanate of Oman, respectively. But it was lower than (19 kg, Almasri, 2010) on Holstein Friesian cows in Syria.

3-Lactation Period (LP):

The LP was $163 \pm 1.45$ days (table 1 ). This estimate was lower than other studies reported by (195.23 days, Basak et al, 2019; 192 days, Toure et al, 2019 and 201 days, Bahashwan, 2020)

4-Dry Period (DP):

The least square mean of dry period was $292 \pm 2.70$ days (table 1). This estimate was higher than the estimates reported by (180 days, Al Amin et al, 2007 and 152 days, Zafar et al, 2008) of North Bengal Grey cows and Pakistani Sahiwal cows.

\section{B-Reproductive traits:}

1-Age at first calving (AFC):

The least square mean of AFC of native Shami cattle in Syria was 30.9 \pm 0.16 months (table 1). This estimate was lower estimates compared to (47.10 months, Ayeneshet et al, 2018; 42.9 months, Basak et al, 2019 and 35.5 months, Bahashwan, 2020) of indigenous dairy cows in Ethiopia, Deoni cows in India and Dhofari cattle in Sultanate of Oman, respectively. But it was hifher estimates (27.1 months, Sadek et al, 1994 and 24.7 months, Lopez et al, 2019) than of Hanwoo Korean Cattle and Friesian cows in Egypt, respectively.

\section{2-Calving Interval (CI):}

The least square mean for $\mathrm{CI}$ in the present study was $454 \pm 2.59$ days (table 1 ). This estimate was in accordance with (453.5 days; Koirala et al, 2011 and 450 days, Toure et al, 2019) of native cattle in Bangladesh and Azawak zebu in Mali, respectively. But it is higher than estimates in some studies (432 days, Sadek et al 1994; 429 days, Zafar et al, 2008; 445.97 days, Basak and Das, 2018 and 439 days, Bahashwan, 2020) of Friesian in Egypt, Sahiwal cow of Pakistan, Deoni Cattle in India and native Dhofari cows in Sultanate of Oman, respectively. In other studies, the mean of CI was lower than estimated in this study (691 days, Ayeneshet et al, 2018 and 498 days, Manzi et al, 2019) of Indigenous Dairy Cows in Ethiopia and Ankole cows in Rwanda, respectively 
Table 1. Least square means $(\mathrm{LSM} \pm \mathrm{SE})$ of productive and reproductive traits for Syrian native Shami cows

\begin{tabular}{ccc}
\hline Studied traits & LSM \pm S.E \\
${ } }$ & & $1503 \pm 17.74$ \\
Daily milk yield (kg) & & $9.1 \pm 0.06$ \\
Lactation length (day) & & $163 \pm 1.45$ \\
Drying of period (day) & & $292 \pm 2.70$ \\
Age at first calving (day) & $30.9 \pm 0.16$ \\
Calving interval (day) & & $454 \pm 2.59$ \\
\hline
\end{tabular}

Number of records $=2654$

\section{2-Effect of nongenetic factors on productive and reproductive traits: \\ Age at first calving (AFC):}

Effect of year of birth on AFC: Table (2) showed the effect of year of birth was significant $(\mathrm{P}<0.01)$ on AFC. It was lowest 29.7 months during the period (1980-1984) and highest 33.2 months during the period (1995-1999). It may be attributed to the changes in feeding and managerial systems and environmental conditions which occurred during years. Our result agreed with Kumar et al (2015) on Frieswal cattle in India and Basak et al (2019) on Deoni cows in India.

Hare et al., (2006) also found a significant reduction in AFC of American cows by 0.25 months during the study period from 1980 to 2004, and explained this to the difference in raising conditions during the years of study, intensive raising led to increased growth rates, thus contributed to the arrival of heifers to puberty age earlier, thus concepted them at an early age, resulted in early calvings.
Otherwise, Sadek et al (1994) and Ardicli et al (2019) showed no significant effect of year of birth on AFC on Friesian cows in Egypt and Holstein cows in Turkey.

Effect of season of birth on AFC: The effect of season of birth on AFC was nonsignificant. The LSM of AFC was ranged between 30.7 and 31.1 months (table 2). Which was in accordance with Sattar et al (2005) of Friesian cows in Pakistan and Ardicli et al (2019). On contrary, Almasri (2010) found the lowest age at the first calving in autumnn (28.36 months) and the highest in the spring (29.85 months) on Holstein Friesian cows in Syria, and who explained it the heifers born in the spring were weaned in the summer, where the grades of high temperature, the quality of feed is not good, and therefore its consumption of feed decreased, so it grew slowly, and therefore concepted at late age, while the heifers born in autumnn weaned in winter, where cold temperatures, increased its consumption of feed, so it grew very quickly, and therefore concepted at an early age of Holstein Friesian in Syria.

Table 2. Effect of year and season of birth on age at first calvingAFC (month)

\begin{tabular}{cc}
\hline Item & Age at first Calving (month) \\
\hline Year of birth & $* *$ \\
$1980-1984$ & $29.7^{\mathrm{a}} \pm 0.40$ \\
$1985-1989$ & $30.6^{\mathrm{ab}^{\mathrm{b}} \pm 0.43}$ \\
$1990-1994$ & $30.6^{\mathrm{ab}} \pm 0.38$ \\
$1995-1999$ & $33.2^{\mathrm{c}} \pm 0.40$ \\
$2000-2004$ & $30.9^{\mathrm{b}} \pm 0.34$ \\
$2005-2009$ & $30.4^{\mathrm{a}} \pm 0.48$ \\
\hline Season of birth & $\mathbf{N S}$ \\
\hline winter & $31.1^{\mathrm{a}} \pm 0.32$ \\
spring & $31.0^{\mathrm{a}} \pm 0.33$ \\
summer & $30.8^{\mathrm{a}} \pm 0.33$ \\
\hline
\end{tabular}

Number of records $=2654 ; * *(\mathrm{p}<0.01) ; \mathrm{NS}=$ not significant.

\section{A-Productive Performance:}

\section{1-Total milk yield (TMY):}

Effect of year of calving on TMY: Table (3) showed the effect of year of calving was significant on TMY. Similar agreement was observed by Basak and Das (2018) and Almasri (2010). Otherwise, Shafig et al (1992) reported the effect of year of calving on TMY was nonsignificant of crossbred cows (Friesian $\times$ Sahiwal) in Pakistan.
Effect of season of calving on TMY: The effect of season of calving on TMY was significant. The difference in TMY between seasons could be attributed to difference climate and feed quality. AlHaidari et al (2002) observed a $24.3 \%$ decrease in lactation milk yield in the hot summer months compared to the winter months in the Holstein cows in Saudi Arabia, and explained this to the thermal stress that led to reduced feed consumption, and consequently reduced production. 
Table 3. Least square means (LSM $\pm \mathrm{SE}$ ) of productive and reproductive traits as affected by year of calving

\begin{tabular}{|c|c|c|c|c|c|c|c|}
\hline \multirow{2}{*}{ studied traits } & \multicolumn{7}{|c|}{ year of calving } \\
\hline & 1981-1985 & 1986-1990 & 1991-1995 & 1996-2000 & 2001-2005 & 2006-2010 & $\mathbf{P}<$ \\
\hline $\begin{array}{c}\text { Calving interval } \\
\text { (day) }\end{array}$ & $567^{\mathrm{c}} \pm 11.14$ & $454^{\mathrm{b}} \pm 8.15$ & $417^{\mathrm{a}} \pm 7.14$ & $418^{\mathrm{a}} \pm 7.38$ & $450^{\mathrm{b}} \pm 6.98$ & $419^{\mathrm{a}} \pm 6.48$ & $* *$ \\
\hline Total milk yield (kg) & $1830^{\mathrm{d}} \pm 72.33$ & $1378^{\mathrm{ab}} \pm 47.48$ & $1319^{\mathrm{a}} \pm 43.23$ & $1386^{\mathrm{ab}} \pm 43.21$ & $1606^{c} \pm 41.41$ & $1499^{\mathrm{bc}} \pm 34.89$ & $* *$ \\
\hline Daily milk yield (kg) & $10.3^{c} \pm 0.23$ & $9.3^{\mathrm{b}} \pm 0.24$ & $8^{\mathrm{a}} \pm 0.23$ & $7.9^{\mathrm{a}} \pm 0.23$ & $9.6^{\mathrm{b}} \pm 0.20$ & $9.3^{\mathrm{b}} \pm 0.21$ & $* *$ \\
\hline $\begin{array}{l}\text { Lactation period } \\
\text { (day) }\end{array}$ & $179^{c} \pm 5.92$ & $146^{\mathrm{a}} \pm 3.92$ & $161^{\mathrm{b}} \pm 3.54$ & $178^{\mathrm{c}} \pm 3.56$ & $159^{\mathrm{b}} \pm 3.40$ & $156^{\mathrm{b}} \pm 2.86$ & $* *$ \\
\hline Dry period (day) & $401^{\mathrm{d}} \pm 17.10$ & $315^{\mathrm{c}} \pm 8.50$ & $249^{\mathrm{a}} \pm 7.54$ & $255^{\mathrm{a}} \pm 7.54$ & $250^{\mathrm{a}} \pm 7.57$ & $284^{\mathrm{b}} \pm 6.24$ & $* *$ \\
\hline
\end{tabular}

Number of records $=2654 ; * *(\mathrm{p}<0.01)$. 
Effect of parity on TMY: Results showed increasing in the TMY with the progress of the parity and up to the fourth parity $1650 \mathrm{~kg}$, then decreased after the Fourth parity (table 5), this could be increase capacity of feed intake compared to the cows of the first parity, and udder glands reached full development, while decreased TMY after the Fourth parity due to increased mortality of secret cells with age. as was also reported by others Al Masri (2010) and Basak and Das (2018). On contrary, Bahashwan (2020) concluded the effect of parity on TMY was nonsignificant.

\section{2-Daily milk yield (DMY):}

Effect of year of calving on DMY: Year of calving was significant $(p<0.01)$ on DMY, Similar results to the present study was also reported by Almasri (2010). Otherwise Chaudhary et al (1996) found no significant effect for the year of calving in the daily milk production in the Holstein Friesian cows in Pakistan.

Effect of season of calving on DMY: The effect of season of calving on DMY was significant, the highest DMY was in spring $(9.4 \mathrm{~kg})$ and summer season $(9.3 \mathrm{~kg})$, and lowest in winter and autumn season $8.8 \mathrm{~kg}$ (table 4). This our result was in agreement with Mostert et al (2001) of cows (Holstein and jersey) in South Africa, the highest daily production of milk was in the coldest months of the year (April to September). Hatungumukama et al (2006) found the highest of DMY in wet season compared dry season because the green feeder was available after calving. in addition to the high temperatures during the dry season, which reduced of feed consumed, thus reduced feed consumed, and thus a decreased in milk produced.

Ayeneshet et al (2018) shoewd the highest of DMY were (2 and 1.75 li) during (Jun-Aug and SepNov month), respectively and the lowest (0.73 and 0.28 li) during (Des-Feb and Mar-May month), respectively of indigenous dairy cows in Ethiopia.

On contrary, Almasri (2010) and Bayou et al (2015) found Season of calving was not significant effect on DMY.

Effect of parity on DMY: The results of the study indicated that daily milk production was highest in the fourth parity and lowest production in the first parity (table 5). Which is due to the cows in their fourth parity increased their milk production. This estimate consistent with Senou et al (2008) in Borgou cows in Benin.

Otherwise, Chaudhary et al (1996) found no significant effect for the parity on the daily milk yield in the Holstein Friesian cows in Pakistan.

Table 4. Least square means (LSM $\pm \mathrm{SE}$ ) of productive and reproductive traits as affected by season of calving

\begin{tabular}{|c|c|c|c|c|c|}
\hline Studied traits & winter & Spring & summer & autumn & $\mathbf{P}<$ \\
\hline $\begin{array}{c}\text { Calving } \\
\text { interval (day) }\end{array}$ & $461^{\mathrm{b}} \pm 6.27$ & $466^{\mathrm{b}} \pm 6.21$ & $453^{\mathrm{ab}} \pm 6.45$ & $438^{\mathrm{a}} \pm 5.29$ & $* *$ \\
\hline $\begin{array}{l}\text { Total milk } \\
\text { yield (kg) }\end{array}$ & $1465^{\mathrm{a}} \pm 36.71$ & $1578^{\mathrm{b}} \pm 36.58$ & $1460^{\mathrm{a}} \pm 37.86$ & $1509^{\mathrm{ab}} \pm 36.88$ & $* *$ \\
\hline $\begin{array}{l}\text { Daily milk } \\
\text { yield (kg) }\end{array}$ & $8.8^{\mathrm{a}} \pm 0.13$ & $9.4^{\mathrm{b}} \pm 0.13$ & $9.3^{b} \pm 0.13$ & $8.8^{\mathrm{a}} \pm 0.13$ & $* *$ \\
\hline $\begin{array}{c}\text { Lactation } \\
\text { period (day) }\end{array}$ & $161^{\mathrm{ab}} \pm 3.02$ & $166^{\mathrm{ab}} \pm 3.00$ & $158^{\mathrm{a}} \pm 3.11$ & $168^{\mathrm{b}} \pm 3.02$ & $* *$ \\
\hline $\begin{array}{l}\text { Dry period } \\
\text { (day) }\end{array}$ & $290^{\mathrm{a}} \pm 6.65$ & $292^{\mathrm{a}} \pm 7.03$ & $293^{\mathrm{a}} \pm 7.25$ & $294^{\mathrm{a}} \pm 6.87$ & NS \\
\hline
\end{tabular}

Number of records $=2654 ; * *(\mathrm{p}<0.01) ; \mathrm{NS}=$ not significant.

\section{3-Lactation Period (LP):}

Effect of year of calving on LP: Result showed the effect of year of calving was significant $(\mathrm{p}<0.01)$ on LP (table 3). Similar results to the present study were also reported by Abou-Bakr et al (2006) of Holstein cows in Egypt and Basak and Das (2018) of Deoni cattle in India.

Effect of season of calving on LP: Table (4) The indicated the effect of season of calving on LP was significant. Which was shortest in summer season (158 days) compared other seasons. may be due to low availability of natural forage and high temperatures during the summer season. This estimate was in agreement with Bayou et al (2015). Cilek and Bakir (2010) observed the LP was longest in winter, due to increased milk production combined with the availability of quality feed in brown cows in Turkey. On contrary, Almasri (2010) found no significant effect for parity on LP.

Parity on LP: The effect of Parity was significant on LP, which was shortest in the first parity (155 days) compared others parities (table 5). Similar agreement was ob served by Basak and Das (2018). In other studies, Cilek (2009) found the LP was longest in first parity (315.3 days) and shortest in fifth parity (285.1 days) of Holstien cows in Turkey. While Kumar et al (2003) reported the effect of parity on lactation length was non-significant in Ongole cattle. 
4-Dry Period (DP):

Effect of year of calving on DP: Result indicated the effect year of calving was significant $(\mathrm{p}<0.01)$ on DP, it was longest 401 days during the period 1981-1985 (table 3). Similar result was also reported by Cilek (2009) and Boujenane (2019) on Holstein cows in Turkey and Iran, respectively. on contrary, Raysildo et al (1983) found nonsignificant effect of year of calving on DP of Ger cows in Brazil.

Effect of season of calving on DP: Table (4) showed the effect of calving season was nonsignificant on DP, which ranged (292-294 days), our result was in agreement with Zafar et al (2008) and Cilek (2009).

On contrary, AbdelGader et al (2007) on Friesian cows in Sudan observed the longest DP in dry season and shortest in wet season because the cows in wet season have long lactation period, so they have short DP, while cows in dry season that have short lactation period, so they have long DP.

Boujenane (2019) observed cows were calved in Fallwinter season had the shortest dry period on Holstein cows in Iran.

Effect of parity on DP: The effect of Parity on DP was significant. It was longest in second parity 317 days compared other parities (table 5). In other studies, by Musa et al (2005) observed the longest of DP in first parity compared others parities of Botana cows in Sudan because of mismanagement and Physiological factors related fertility traits. Zafar et al (2008) found the longest DP was 199 days in the first parity and the shortest 150 days in the nine parity of Sahiwal cows in Pakistan. Whereas, Boujenane (2019) showed primiparous cows had lower dry period than multiparous.

Otherwise, Kenan et al (2005) found no significant effect of parity on DP.

\section{B-Reproductive performance}

\section{1-Calving Interval (CI):}

Effect of year of calving on CI: Results in this study showed significant effect of year of calving on CI (table 3). The difference in CI between periods could be attributed to variation in management condition, climate and feed quality.

Similar results to the present study were also reported by Almasri (2010) and Bahashwan (2020). Otherwise, no significant effect of year of calving on CI was reported by Basak and Das (2018).

Effect of season of calving on CI: season of calving showed significant effect on CI (table 4). This can be due to the variation in feed quality and climate between the seasons, the present finding was in agreement with the reported by Mekonnen et al (2011) on Horro cows and Ardicli et al (2019) on Holstein cows in Turkey.

In other studies, conducted by Bahashwan (2020) and Almasri (2010) reported the nonsignificant effect of season of calving on CI.

Effect of Parity on CI: Table (5) indicated CI was significantly affected $(\mathrm{p}<0.01)$ by parity. The shortest CI was 437 days in fourth parity compared other parities. This may attribute to the increase in body weight with age to reach full development, resulting in activity in the reproductive system. This result is in agreement with Mureda and Zeleke (2007) on crossbred dairy cows in Ethiopia and Bayou et al (2015) on Sheko cattle in Ethiopia.

Getinet et al (2009) reported the longest CI in young cows which might be due to lower energy balance as they are not able to consume more for their own growth, production, reproduction and maintenance, thus lower energy balance delays the onset of postpartum heat.

Otherwise, Almasri (2010) and Bahashwan (2020) showed the Parity did not have significant effect on CI. 
Table 5. Least square means $(\mathrm{LSM} \pm \mathrm{SE})$ of reproductive and productive traits as affected by parity

\begin{tabular}{|c|c|c|c|c|c|c|}
\hline studied traits & 1 & 2 & 3 & 4 & $\geq 5$ & $\mathbf{p}<$ \\
\hline $\begin{array}{c}\text { Calving interval } \\
\text { (day) }\end{array}$ & $465^{\mathrm{b}} \pm 5.47$ & $454^{\mathrm{ab}} \pm 3.02$ & $450^{\mathrm{ab}} \pm 2.41$ & $437^{\mathrm{a}} \pm 3.09$ & $465^{\mathrm{b}} \pm 3.29$ & $* *$ \\
\hline Total milk yield (kg) & $1194^{\mathrm{a}} \pm 34.53$ & $1514^{\mathrm{b}} \pm 38.49$ & $1600^{\mathrm{bc}} \pm 44.32$ & $1650^{c} \pm 51.52$ & $1556^{\mathrm{bc}} \pm 40.28$ & $* *$ \\
\hline Daily milk yield (kg) & $7.5^{\mathrm{a}} \pm 0.12$ & $9.1^{\mathrm{b}} \pm 0.14$ & $9.7^{\mathrm{c}} \pm 0.16$ & $9.7^{\mathrm{c}} \pm 0.18$ & $9.3^{\mathrm{bc}} \pm 0.14$ & $* *$ \\
\hline $\begin{array}{l}\text { Lactation period } \\
\text { (day) }\end{array}$ & $155^{\mathrm{a}} \pm 2.83$ & $164^{\mathrm{b}} \pm 3.16$ & $165^{\mathrm{b}} \pm 3.64$ & $168^{\mathrm{b}} \pm 4.23$ & $163^{\mathrm{b}} \pm 3.31$ & $* *$ \\
\hline Dry period (day) & $287^{\mathrm{a}} \pm 6.59$ & $317^{\mathrm{b}} \pm 8.15$ & $295^{\mathrm{a}} \pm 7.03$ & $276^{\mathrm{a}} \pm 6.07$ & $287^{\mathrm{a}} \pm 6.59$ & $* *$ \\
\hline
\end{tabular}

Number of records $=2654 ; * *(\mathrm{p}<0.01)$ 


\section{Conclusion}

Improve management conditions and genetic improvement for Syrian native Shami cows could be improve reproductive performance that leads to increase milk yield and number of calvings of their cows.

\section{Acknowledgment}

The authors would like to thank the Institute of International Education's Scholar Rescue Fund (IIESRF) for funding publication of this research.

\section{Reference}

Azizunnesa. 2002. Economic opportunity survey of Rahman, M.F., 1993. An economic study of dairy the subsistence dairy farm in Mymensingh district. Bangladesh Agricultural University, Mymensingh.

AbdelGader, A., A. A. Mohamed-Khair, LM-A. Musa and K. J. Peters. 2007. Milk yield and reproductive performance of Friesian cows under Sudan tropical conditions. Arch. Tierz., Dummerstorf. 50(2):155-164.

Abou-Bakr, S., H.O.A. Alhammad, R.R. Sadek and A.A. Nigm. 2006. Productive and reproductive characteristic of Holstien cows raised under intensive farming systemin Egypt. Egyptian J. Anim. Prod. 43(2):91-98.

Al-Amin, M., A. Nahar, A.K.F.H. Bhuiyan, and M. O. Faruque. 2007. On farm characterization and present status of North Bengal Grey (NBG) cattle in Bangladesh. AGRI. 40: 55-64.

Alemayehu, T. and N. Moges. 2014 Study on Reproductive Performance of Indigenous Dairy Cows at Small Holder Farm Conditions in and Around Maksegnit Town. Global Veterinaria 13: 450-454.

Al-Haidari, A., A., Al-Saghir and M. Al-Sheikh. 2002. The effect of thermal stress on milk production and in some thermal responses to high-production Holstein cows in the semi-dry environment. Journal of King Saud University, M14, Agricultural Sciences. 1: 45 -54.

Almasri., O. 2010. Analysis Study for the Productive and Reproductive Traits of Holstein Friesian Cattle at Kharabo Dairy Farm. Master's thesis. Damascus University Syria.

Ardicli, S., H. Samli, B. Soyudal, D. Dincel and F. Balci. 2019. Evaluation of candidate gene effects and environmental factors on reproductive performance of Holstein cows. South African Journal of Animal Science. 49 (2):380-394.

Ayeneshet, B., M. Abera and Z. Wondifraw. 2018. Reproductive and Productive Performance of Indigenous Dairy Cows under Smallholder Farmers Management System in North. J. Fisheries Livest Prod. 6 (1):2-5.
Bahashwan, S. 2020. Dhofari cattle breed; productive and reproductive performance. Livestock Research for Rural. 32(2):

Basak, S. and D. Das. 2018. Effect of Parity, Period and Season of Calving on Production and Reproduction Traits on Deoni Cattle. Journal of Animal Health and Production. 6(1):1-4.

Basak, S., D.N. Das and U.T. Mundhe.2019. Genetic and non-genetic factors affecting productive and reproductive traits in Deoni cattle. Indian J. Anim. Res. 53: 699-703.

Bayou E, Haile A, Gizaw S, Mekasha Y. 2015. Evaluation of non-genetic factors affecting calf growth, reproductive performance and milk yield of traditionally managed Sheko cattle in southwest Ethiopia. Springer plus. 40:865.

Boujenan, I. 2019. Factors Affecting the dry period length and its effect on milk production and composition in subsequent lactation of Holstein cows. Iranian Journal of Applied Animal Science. 9(2): 229-234.

Chagas, L. M., J. J. Bass, D. Blache, C. R. Burke, J. K. Kay, D. R. Lindsay, M. C. Lucy, G. B. Martin, S. Meier, F. M. Rhodes, J. R. Roche, W. W. Thatcher, and R. Webb. 2007. Invited Review: New perspectives on the roles of nutrition and metabolic priorities in the subfertility of highproducing dairy cows. J. Dairy Sci. 90:4022-4032.

Chaudhary, M. 1., M. Rafiq and M. A. Amar. 1996. Performance of various genetic groups of Holstein-Friesian crossbreeds. 1ih Ann. Report. (1995-96). Livestock Production Research Institute, Bahadurnagar, Okara (Pakistan).

Cilek, S. 2009. Reproductive Traits of Holstein Cows Raised at Polatlı State Farm in Turkey. J. Anim. Vet. Adv. 8(1):1-5.

Cilek, S. and G. Bakir. 2010. Milk Yield Traits of Brown Cows Reared at Malya State Farm and Effects of Some Environmental Factors on These Traits. Kafkas Univ Vet Fak Derg. 16(2):347-350.

Getinet, M., A. Workneh and B. P. Hegde. 2009. Growth and reproductive performance of Ogaden cattle at Haramaya University, Ethiopia. Ethiopian Journal of Animal Production 9 (1):13-38.

Hare, E., H. D. Norman and J. R. Wright. 2006. Trends in Calving Ages and Calving Intervals for Dairy Cattle Breeds in the United States. J. Dairy Sci. 89:365-370.

Hatungumukama, G., D. S. Idrissa, P. L. Leroy, J. Etilleux. 2006. Effects of non-genetic and crossbreeding factors on daily milk yields of Ayrshire x (Sahiwal x Ankole) cows in Mahwa station Burundi). Livest. Sci. 110:111-117.

Kenan, M., H. Erbay and A. Nazligul. 2005. Effect of Some Factors on Milk Yield in Holstein Cows. Kafkas Univ. Vet. Fak. Derg. 11(1): 69-72.

Koirala, B., M. Z. Alam, A. Iqbal and A. K. F. H. Bhuiyan. 2011. Study on morphometric, productive and reproductive traits of native cattle 
at Sylhet district. J. Bangladesh Agri. Univ. 9(1): 85-89.

Kumar, D.K., C.E. Reddy, B.R. Gupta and A. Satyanarayana. 2003. Effect of year, season and lactation order on the performance of Ongole cattle. Indian J. Anim. Sci. 73(11): 1289-1290.

Kumar, J., Y. P. Singh, S. Kumar, R. Singh, R. Kumar and P. Kumar. 2015. Genetic analysis of reproductive performance of Frieswal cattle at Military Farm, Ambala. Veterinary World. 8:1032-1037.

Lopez, B.I., J.H. Son, K. Seo and D. Lim. 2019. Estimation of Genetic Parameters for Reproductive Traits in Hanwoo (Korean Cattle). Animals 9(715):2-7.

Manzi, M., L. Rydhmer, M. Ntawubizi, C. Karege, and E. Strandberg. 2019. Reproductive performance of Ankole cattle and its crossbreds in Rwanda. Tropical Animal Health and Production. 51:49-54.

Masama, E., N. T. Kusina, S. Sibanda and C. Majoni. 2003. Reproductive and lactational performance of cattle in a smallholder dairy system in Zimbabwe. Tropical Animal Health and Production 35: 117-129.

Mekonnen, A., A. Haile, T. Dessie and Y. Mekasha .2011. On Farm Evaluation of Growth and Reproductive Performance of Horro Cattle Breed in Western Oromia, Ethiopia. J Anim Feed Res.

Mostert, B. E., H. E. Theron and F. H. J. Kanfer. 2001. The effect of calving season and age at calving on production traits of South African dairy cattle. J. Anim. Sci. 31(3):205-214.

Mureda, E. and M. Zeleke .2007. Reproductive Performance of Crossbred Dairy Cows in Eastern lowlands of Ethiopia. Livestock Research for Rural Development 19.

Musa, L. M-A., M-K. A. Ahmed, K. J. Peters, B. Zumbach and K. E. A. Gubartalla. 2005. The reproductive and milk performance merit of Butana cattle in Sudan. Arch. Tierz. Dummerstorf 48(5):445-459.

Raysildo, B. L., E. B. de Oliveira Filho, F. A. M. Duarte, A. A. M. Goncalves and A. A. Ramos.
1983. Effects of age at First calving, Gestation Length and Dry period on milk yield in aGir Herd. Rev.Brasil.Genet. 2:307-318.

Sattar, A., R. H. Mirza, A. A. K. Niazi and M. Latif. 2005. Productive and reproductive performance of Holstein Friesian cows in pakistan. Pakistan Vet. J .25(2):75-81.

Sadek, R.R., E. A. Helali, M.A. Safwat, S.A.M. Ibrahim and A. Abd El-Fatah. 1994. Evaluation of Friesian cattle performance in commercial farms in Egypt. J.Anim.Prod. 31(1):43-64.

Sawa A., Bogucki M. and Neja W. (2012). Dry period length and performance of cows in the subsequent production cycle. Arch. Tierz. 55(2), 140-147.

Sawa A., Bogucki M. and Siatka K. (2013). Effect of the first and next calvings of cows and their milk production level on the relationship between dry period length and milk yield and its composition in the subsequent lactation. Arch. Tierz. 56(95): 934-942.

Sawa, A., K. Siatka and S. Krężel-Czopek. 2019. Effect of age at first calving on first lactation milk yield, lifetime milk production and longevity of cows, Annals of Animal Science, DOI: 10.2478/aoas-2018-0044.

Senou, M., S. S. Toleba, C. Adandedjan, J. P. Poivey, A. Ahissou, F. Z. Toure and C. Monsia. 2008. Increased Milk Yield in Borgou Cows in Alternative Feeding Systems. Revue Élev. Méd. vét. Pays trop. 61(2) : 109-114.

Shafig, M., A. Khan, A. Rehman, P. Akhtar, M. A. Awan. 1992. Effect of year and season of calving on some economic traits in Friesian- Sahiwal Halfbreds. J.Pakistan Vet. 12: 170-173.

Toure, A., N. Antoine-Moussiaux, F. Geda, A. Kouriba, D. Traoré, B. Traore, P. Leroy and N. Moula. 2019. Phenotypic parameters affecting reproduction and production performances of dairy cattle in peri-urban of Bamako, Mali. Veterinary World.817-822.

Zafar, A. H., M. Ahmad and S. U. Rehman. 2008. Study of some Performance Traits in Sahiwal Cows during different Periods. Pakistan Vet. J. 28(2):84-88. 